\title{
Communication as a strategy for hospital accreditation maintenance $^{a}$
}

\author{
A comunicação como estratégia para manutenção da acreditação hospitalar \\ La comunicación como estrategia para el mantenimiento de la acreditación hospitalaria
}

Elana Maria Ramos Freire ${ }^{1}$

Valéria Cristina da Silva ${ }^{1}$ (C) Adriane Vieira ${ }^{1}(\mathbb{C})$

Selme Siqueira de Matos $^{1}(1)$

Marília Alves ${ }^{1}$ (ib)

1. Universidade Federal de Minas Gerais. Belo Horizonte, MG, Brasil

Corresponding author:

Valéria Cristina da Silva.

E-mail:valeria.enf.ufmg@gmail.com.

Submitted on $07 / 28 / 2018$

Accepted on 11/23/2018.

DOI: 10.1590/2177-9465-EAN-2018-0224

\section{Abstract}

Objective: to analyze the communication strategies adopted by a General Hospital, which helped the accreditation's maintenance with excellence. Method: case study of a Private Hospital in Belo Horizonte, Brazil, accredited with excellence. Data were collected through semi-structured interviews and through analysis of institutional documents. The interviews were transcribed in full and submitted to content analysis. Results: instigating organizational and behavioral changes that have generated insecurity and resistance in employees. The development of strategies to improve internal communication contributed to the uniformity of information and the greater integration of professionals in their actions, promoting the change in the workers' attitudes, and engaging and involving them in the process. Conclusion: communication plays a prominent role in the consolidation of hospital care and the development of a priority strategy to reach and maintain it, with an emphasis on quality of care and patient safety.

Keywords: Accreditation; Hospitals; Communication; Strategies; Quality Management.

\section{Resumo}

Objetivo: analisar as estratégias de comunicação adotadas por um Hospital Geral, que colaboram para manutenção da acreditação com excelência. Método: estudo de caso de um Hospital Privado de Belo Horizonte, Brasil, acreditado com excelência. Os dados foram coletados por meio de entrevistas com roteiro semiestruturado e análise de documentos institucionais. As entrevistas foram transcritas na íntegra e submetidas à análise de conteúdo. Resultados: a acreditação provocou mudanças organizacionais e comportamentais que inicialmente geraram insegurança e resistência nos colaboradores. O desenvolvimento de estratégias para melhoraria da comunicação interna contribuiu para uniformidade das informações e maior compreensão por parte dos profissionais sobre suas ações, promovendo, assim, mudanças nas atitudes dos trabalhadores, tornando-os engajados e envolvidos com o processo. Conclusão : a comunicação assume papel de destaque para consolidação da acreditação hospitalar e deve ser estratégia prioritária para alcance e manutenção da mesma, visando à qualidade assistencia e a segurança do paciente.

Palavras-chave: Acreditação; Hospitais; Comunicação; Estratégias; Gestão da Qualidade.

\section{REsumen}

Objetivo: analizar las estrategias de comunicación adoptadas por un Hospital General para el mantenimiento de la acreditación con excelencia. Método: estudio de caso de un hospital privado de Belo Horizonte, Brasil, acreditado con excelencia. Los datos fueron recolectados por medio de entrevistas con un guión semi-estructurado y el análisis de documentos institucionales. Las entrevistas fueron transcritas en su totalidad y sometidas al análisis de contenido. Resultados: la acreditación causó cambios organizacionales y comportamentales que generaron inseguridad y resistencia en los colaboradores inicialmente. El desarrollo de estrategias para mejorar la comunicación interna contribuyó a la uniformidad de las informaciones y más integración por parte de los profesionales en sus acciones, promoviendo el cambio en las actitudes de los trabajadores, haciéndolos comprometidos e involucrados con el proceso. Conclusión: la comunicación asume un papel destacado para la consolidación de la acreditación hospitalaria y el desarrollo de estrategia prioritaria para el alcance y mantenimiento de la misma, con énfasis en la calidad asistencial y la seguridad del paciente.

Palabras clave: Acreditación; Hospitales; Comunicación; Estrategias; Gestión de la Calidad. 


\section{INTRODUCTION}

Patient safety is an important dimension of the quality of health care, as well as a topic that has called the attention of researchers worldwide, as well as the World Health Organization (WHO) agenda 1 . Therefore, many hospitals have recognized the need to develop strategies for improving services and minimizing the occurrence of errors, such as the implementation of hospital accreditation programs ${ }^{2}$.

The Brazilian accreditation system, operated by the Organização Nacional de Acreditação (ONA - National Accreditation Organization), seeks to promote the development of permanent processes for evaluating and certifying the quality of health care, through previously defined standards ${ }^{3}$. These efforts arise in a context of user dissatisfaction, which requires improvements and safety of health services, with efficient use of resources ${ }^{4}$.

As in the results of studies ${ }^{4,5}$, we start from the assumption that the implantation and the reach of accreditation certification are associated to changes in the organizational culture, especially in the communication process, since the orientation on the performance of each actor, the adequate information disclosure, preparation and awareness of the teams regarding the objectives of accreditation are decisive for the achievement and maintenance of certification.

The result of a favorable communication makes it possible to standardize actions, share knowledge and values, and facilitate relations with the internal and external public ${ }^{6}$. According to the $\mathrm{WHO}$, communication is one of the five main problems that affect patient safety; therefore, actions aimed at improving the process of issuing and spreading information are part of the global guidelines for standardization and implementation of protocols for the reduction of adverse events, increased safety and quality of care ${ }^{7}$. Studies carried out by the Joint Commission International $(\mathrm{JCl})$ point out that ineffective communication has been the root cause of more than $60 \%$ of adverse events in the world between 2013 and $2015^{8}$.

Achieving and maintaining accreditation requirements, therefore, are directly related to sense production and behavior change, which should occur when individuals are sensitized about the need to improve their work processes. Strategies that promote the improvement of communication must be present in the organizational routine to align the organizational goals with the actions of individuals and teams, as well as to awaken the sense of belonging and proactive actions, through the deployment of guidelines and strategies at all hierarchical levels ${ }^{9}$. Unsuccessful communication can pose a threat to institutional relations ${ }^{10}$, generating insecurity and demotivation of professionals because they did not understand the process of quality management ${ }^{4}$.

In Brazil, three accreditation methods are used in hospitals: the Sistema Brasileiro de Acreditação (SBA-ONA - Brazilian Accreditation System); the Joint Commission International $(\mathrm{JCl})$, based on the North American model; and Accreditation Canada International $(\mathrm{ACl})$ recently renamed Health Standards Organization (HSO), represented in Brazil by the Instituto
Qualisa de Gestão (IQG - Qualisa Institute of Management). The methodology adopted by the vast majority of hospitals in the country is the ONA, with 302 hospital certifications ${ }^{11}$, followed by the $\mathrm{ACl}$, with 48 accredited hospitals ${ }^{12}$, and 37 hospitals certified by $\mathrm{JCl}^{13}$

According to the ONA methodology, health institutions can receive three levels of certification, with increasingly complex and interdependent standards: level 1 or accredited, related to safety, structure, processes and risk management with a focus on security throughout the organization; level 2 or fully accredited, involving the integrated management and interaction of processes and institutional results, with critical analysis and improvement cycles; and level 3, or accredited with excellence, covering organizational maturity, continuous improvement culture, creativity and sustainability ${ }^{3}$. Maintaining this latter level, therefore, requires effective communication strategies in order to promote culture and behavioral changes.

The ONA ${ }^{3}$ methodology contains the necessary requirements for achieving and maintaining the level of excellence, however, it is up to each institution to outline the strategies for their operation. In this study, we adopt as a theoretical reference the strategy as a practice ${ }^{14}$ with a focus on what practitioners do, or on how people work in the organizational daily of strategy creation.

Strategy as a practice seeks to shift focus from the effects of strategies on organizational performance to a more indepth analysis of what actually happens in the planning and implementation of strategies and related activities ${ }^{15}$. Researches involving organizational strategies, in general, are related to the formulation of strategic planning. However, studies regarding how strategies are put into practice, as well as barriers, facilities and implementation challenges are still not very expressive in the set of knowledge produced in the field ${ }^{16}$, justifying the accomplishment of this research. In light of the above, this study had as an analysis the communication strategies adopted by a General Hospital, which collaborate to maintain accreditation with excellence.

\section{METHOD}

The research method adopted was a qualitative and descriptive unique case study defined by Yin as an empirical investigation in which the researcher has little control over the event studied, and seeks to understand it in depth to retain the significant characteristics of the phenomenon in its real context ${ }^{17}$.

The study scenario was a large private General Hospital located in the city of Belo Horizonte, Accredited Full by ONA since 2008 and Accredited with Excellence since 2010, which demonstrates evolution in the quality management system. The hospital is also certified by ISO 9001 and ISO 31000 and by the National Integrated Accreditation for Healthcare Organizations (NIAHO), which represents the recognition of a Brazilian hospital of international standard.

Recruitment of the research participants occurred intentionally after contact with the hospital to obtain information 
about recent process changes and insertion of new professionals that participated in the decisions, considering the capacity to provide adequate answers to the research objectives. The interviewees were selected according to the following inclusion criteria: participate directly in the decisions and actions related to the quality certification, employment contract of at least one year in the hospital and have experience in conducting the accreditation process at the strategic and intermediate levels. The exclusion criteria adopted were: not to have participated in decisions related to accreditation and to be away from the hospital for different reasons at the time of collection of data.

From the inclusion criteria, at the strategic level, a Clinical Director, a Technical Director, the Controllership's Professional, a Nursing Manager, a Supervisor and a Quality Advisory were interviewed. From the intermediate level, Coordinators of Functional Units and Administrative Nurses were interviewed and, at the operational level, Assisting Nurses for the consolidation of the hospital quality project. During the research, the Hospitality Manager, the Patient Safety Center Nurse (PSC) and the Hospital Epidemiology Service Nurse (HES) were included because they were indicated by the participants as key informants, or subjects with information relevant to understanding the phenomena ${ }^{18}$.

The data were collected in a meeting room of the hospital, through individual interviews, using a semi-structured script, recorded with the consent of the participants with a signed Free Informed Consent Form, and they were transcribed in full. A pilot test of the script was carried out with other professionals who were not part of the research to verify the participants' understanding and adequacy to the objectives and had the following questions: how does the hospital prepare the staff to maintain accreditation level 3 until the next evaluation? What actions have been taken daily to maintain the quality of services required by accreditation level 3 with excellence? How is the internal information disclosure of these actions performed?

It should be emphasized that the number of interviewees was defined during the data collection, using the saturation criterion, which consists of the interruption of the interviews when obtaining redundant information and with little new addition to the topics covered ${ }^{19}$. The interviews were numbered according to the sequence, and to maintain the anonymity of the participants the following were used: SM for Strategic Managers, NC for Nurses and Coordinators of functional units; AdN for Administrative Nurses; NA for Nursing Assistants, and KI for Key Informants. In total, 22 professionals from different backgrounds were interviewed: 06 (six) from the strategic level, 09 (nine) from the intermediate level and 7 (seven) from the operational level.

The collected information was submitted to thematic content analysis in three phases: pre-analysis, material exploration and treatment of results, inference and interpretation ${ }^{20}$. First all the material was organized and carried out a "leitura flutuante" (freely translated as floating reading, which is an activity that aimed to generate initial impressions about the material to be analyzed), making possible the detection of the first impressions of the data content. In the phase of exploration of the material, we carried out an exhaustive reading, marking of the text and cut of the Registry Units. Through the exhaustive reading, the process of codification and categorization of the topics raised was organized, organizing the "Registry Units" into two categories: implications of communication for hospital accreditation; and communication strategies for quality improvement and maintenance of accreditation. After the categorization, the contents were analyzed, with interpretation and data inferences based on the literature and theoretical reference adopted ${ }^{14,20}$.

The study was approved by the Ethics and Research Committee of the Universidade Federal de Minas Gerais, CAAE42096015.3.0000.5149, under Opinion 1,018,224. All participants were informed about the purpose of the study and signed the Informed Consent Term.

\section{RESULTS}

Of the 22 professionals interviewed, 17 were nurses; two were doctors; one was hotel manager; one was nutritionist and one accountant. The nurses occupied strategic positions (2), intermediate (8) and care/operational positions (7). There was a predominance of female participants (17), the age range ranged from 25 to 56 years, and the time spent in the hospital between one year and a half to 35 years.

\section{Implications of communication for hospital accreditation}

Respondents naturally stressed the importance of communication when questioned about the strategies adopted by the hospital to prepare staff to maintain accreditation level 3 . They mentioned that at the beginning of the certification process the communication was quite diffuse, because the information was centralized in the management group and in the coordinators of the units; the decisions were taken by the Quality Advisory and by the top management, who outlined the strategies for the certification and the employees. This way of managing the accreditation implementation process prevented the operational level from understanding the real reasons for certification actions, which caused resistance to changes.

Before there was a huge failure in communication. The information was not released. There were people who thought and created strategies: - We're going to work this way! But no one knew why. This information was not passed, the reason why we are working this way. (AdN 3$)$

It started slowly, and at first the staff was more resilient. The big change from the beginning to the present has been the involvement of the front line staff. Previously, the involvement was more of the managers, of the leaderships that went in the meetings and later passed the information to the staff of the front line. (NA4)

Over time, as operational-level employees understood the importance of accreditation to the hospital and the users, and 
how strategies developed by the strategic and intermediate level would lead to quality improvement, they felt involved in the process implementation of innovation and more willing to participate in the decisions deployment, allowing them to change their daily practices. It is possible to affirm, then, that managers and collaborators went through a process of maturation on the importance of communication in the daily work, creating own strategies, in the organizational daily, that favored the accreditation.

According to informants, there is now a greater integration of the clinical staff, coordinators and other workers with the quality management system, because the hospital invested in the improvement of the internal communication, so that the information reaches the employees of all levels of the organizational structure, especially those who provided direct patient care. This strategy resulted in greater adherence of the teams to the accreditation process, breaking with the dichotomy of thinking and acting, facilitating the professionals' understanding and reflection on the work carried out.

We have been performing on-the-spot trainings, courses, summaries of what a certification is, what the levels of accreditation are. We were taking it slowly to them and arguing day by day, showing the foundation. Because only doing because they have to do, everyone does. We have to justify for people. So we surround this, we take the information ... we conducted a survey of the need for the information too, to communicate better and achieve compliance. (NC2)

I work here for my organization, for the well-being of everyone, especially the patient. I have to do my best, I cannot do it wrong, or if I make a mistake I have to have a contingency plan. So this information did not exist before, but today it is well disseminated. People come to understand why they have to walk right and not because of the audit alone. (AdN3)

The understanding that actions should be present only at audit times has given way to the understanding that the primary focus is the end consumer, the patient. In the report, there is an attitude of belonging, of which the work is performed for greater organization of the service and for the well-being of all.

\section{Communication strategies for quality improvement and maintenance of accreditation}

In the reports of the participants, it was possible to show that the strategies for improving communication consist of daily actions inserted in the hospital practice, from an informal conversation to formal meetings to analyze indicators. These actions are often not valued in hospital organizations, for their simplicity and for not demanding complex or costly resources.

For participants, one of the strategies for effective communication was the development of hospital strategic planning at different hierarchical levels, which involved all employees in the organizational processes for accreditation, to ensure that they acted on a common goal.

In fact we want to put a culture of the inverted pyramid, the people of the tip are even more important than the heads of management. Instead of being top-down, we expect it to be bottom-up because we cannot carry out the plan if at the end who actually does not engage. (SM2)

The efforts for effective communication focused on information disclosure regarding quality management and accreditation to the front line staff, for which the hospital used written and oral communication strategies. In the written communication, the information was sent by e-mail, intranet, whatsapp group, billboard, wall newspaper, management board and desktop background (Chart 1), each coordinator being responsible for the scope and access of this information by his team.

Oral communication mainly took place through meetings and trainings. There were sector meetings, quality meetings, meetings with the board of directors, among others, in which decisions were passed on, discussion of actions for quality improvement, guidelines on standards for certification and how to comply with them, and the degree of autonomy of the coordinators and team in front of the actions to be developed (Chart 2).

In the meeting with the board, called ACAD, and in meetings with the quality, it was mandatory the presence of a representative of each sector of the hospital. This representative could be the coordinator or a professional appointed by him, as long as he was able to present and discuss the results of his sector and pass the content to the team. In general, the meetings were periodic and varied according to subject, objectives and needs.

Oral communication strategies adopted by the hospital involved from the professionals on call in the sectors to the direction. The periodicity and complexity of information was different for operational and strategic levels, aiming to reach all sectors and collaborators through collective discussions. Urgent or specific information for a unit or on-call was discussed in a quick manner, such as at the so-called "dedo de prosa" (Brazilian expression meaning chatting) and "se vira nos 15" (Brazilian expression meaning the obligation to be efficient in a difficult situation in a short time) meetings, at the unit itself, giving a direction compatible with the project for continuity of actions for quality in the everyday hospital. More complex issues, such as analysis of indicators or targets, were discussed monthly or semi-annually, with coordinations and senior management, respectively. The content was passed on to all the employees of the units, promoting the knowledge of the actions, adjustments and corrections to be carried out by the staff of the front line.

It was also observed an initiative called Projeto Sol e Lua (freely translated as Sun and Moon Project) whose focus was the continuity of qualified professional practice during the night shift. The project consisted of mechanisms to standardize communication and quality improvement actions throughout the 
Chart 1. Written communication strategies, $\mathrm{X}$ Hospital, Belo Horizonte

\begin{tabular}{ll}
\hline $\begin{array}{c}\text { Type of } \\
\text { Comunication }\end{array}$ & \multicolumn{1}{c}{ Description } \\
\hline Intranet & $\begin{array}{l}\text { Online page of the hospital of restricted access to the employees, where the Standard Operational } \\
\text { Procedures (SOP), SPR (Systemic Procedures), guide of medicines used, quality page with information on } \\
\text { the quality management system are available, among other information about the hospital. }\end{array}$ \\
Jornal mural & $\begin{array}{l}\text { Internal print with quality information and achievements of the hospital, being available in strategic } \\
\text { locations to facilitate access of employees, such as in the cafeteria, locker rooms and corridors. }\end{array}$ \\
Billboard & $\begin{array}{l}\text { A board where posters and internal reports on changes in processes, new routines, quality information are } \\
\text { placed. }\end{array}$ \\
$\begin{array}{l}\text { Management } \\
\text { board }\end{array}$ & $\begin{array}{l}\text { A board is located in all sectors, which includes a strategic map of the hospital; strategic indicators of each } \\
\text { sector that are associated with the hospital's strategic goal and objectives. }\end{array}$
\end{tabular}

Chart 2. Oral communication strategies, $X$ Hospital

\begin{tabular}{cc}
\hline $\begin{array}{c}\text { Type of } \\
\text { Comunication }\end{array}$ & Description
\end{tabular}

\begin{tabular}{|c|c|}
\hline $\begin{array}{l}\text { Análise Crítica para } \\
\text { Alta Direção (ACAD) }\end{array}$ & $\begin{array}{l}\text { Semi-annual meetings between the main leaders, sector coordinators and the board, in which there } \\
\text { is presentation and critical analysis of all the indicators of each sector, with action plan and change } \\
\text { management. }\end{array}$ \\
\hline Quality meetings & $\begin{array}{l}\text { They are weekly and mandatory meetings. The Quality Advisory team participates and a } \\
\text { representative from each sector. Systemic information, accreditation updates, industry requirements } \\
\text { and activities to be performed are discussed. The difficulties of the sectors and what needs to be } \\
\text { improved are also pointed out. }\end{array}$ \\
\hline $\begin{array}{l}\text { Patient Safety } \\
\text { Center Meetings }\end{array}$ & $\begin{array}{l}\text { They occur every fortnight to discuss issues related to patient safety and critical analysis of adverse } \\
\text { events occurring with the participation of a multiprofessional team, including those involved in the } \\
\text { event. }\end{array}$ \\
\hline $\begin{array}{l}\text { Meetings with coor- } \\
\text { dinations }\end{array}$ & $\begin{array}{l}\text { Discussion of the results of the month between the team with their coordinators, with critical } \\
\text { analysis of the indicators, preparation of action plans to adjust the goals not reached and review } \\
\text { them if necessary. }\end{array}$ \\
\hline $\begin{array}{l}\text { Sectoral meetings: } \\
\text { dedo de prosa; se } \\
\text { vira nos } 15\end{array}$ & $\begin{array}{l}\text { They are weekly or according to the demand of each care unit, with the participation of all the } \\
\text { professionals of the shift. There is information disclosure from quality meetings, news from the } \\
\text { hospital, changes in routines and processes, and monitoring activities. These meetings are quick and } \\
\text { objective and aim to give wide information dissemination about the hospital's daily routine. }\end{array}$ \\
\hline $\begin{array}{l}\text { Individual Orienta- } \\
\text { tions }\end{array}$ & $\begin{array}{l}\text { Quality Advisory promotes individual orientations with members of the sectors when difficulties are } \\
\text { identified in the understanding and execution of the activities proposed by the quality, in order to } \\
\text { assist in the development of the activity. }\end{array}$ \\
\hline
\end{tabular}

Source: research data.

hospital in the 24 hours. Coordinators should develop strategies for passing on information, conducting training and internal audits during day and night shifts. Safe and qualified care should be provided full-time in the hospital, effective communication being essential for engaging night staff, collaborating to build a unique quality culture.

What is established for the day is for established the night time too. The first thought that has to come out of my head is that I have two hospitals, one running during the day and one running at night. I have the same hospital and the same team working at different times. This has to be understood by me as coordination and has to be understood by my area professionals. (NC1)

Also, I audition for night shift, it's ... several meetings are held with the night nurses, both with the coordinator and with all the nurses, we have meetings with the night and daytime together, they know they have an audit, I've stayed several times at night, so they can understand the process, because the night really is...they end up not doing as correctly as they have to do, like identification of the label, that medication they end up not filling everything due to lack of habit, due to having someone there looking watching 
and punctuating, understood? So from the moment they realize that there is someone observing that we are really watching, they begin to change, as it has changed. (KI2)

The report of NC1 and KI2 shows the need to think of the hospital as a whole in the 24 hours, in a homogeneous way, overcoming the discontinuity of the daytime actions at night, which are often justified and related to the reduction of the number of nursing staff and overload of work.

In the hospital under study, the Quality Advisory is the link between the board and the sectors, being responsible for the deployment of information for all the units, as well as for the monitoring and control of the established actions. There were guidelines for what was to be done; however, each field coordinator defined his strategies to reach the objectives with the support of the Quality Advisory.

For example, safe transportation of patient is a requirement, it has to do. Is there in the hospitalization unit, the quality will charge me the requirement, but as the requirement will be met is the management of the industry that dismembers with the team. (NC3)

We realize that a lot of information stops in the lead and does not have the deployment to the area. Then, we will get closer to the nurses (caregivers) in the area, charging, being that little dentist, for him and his team to buy our idea. We always start by training the nurses, who replicate, they deploy the information to the nursing technical team. (AdN1).

Therefore, the reports confirm the effectiveness of the deployment of strategic information for the different professionals, promoting greater autonomy for decision making and greater involvement of care levels with actions to improve hospital quality.

\section{DISCUSSION}

The evaluation of health quality is gaining importance worldwide, driven by the demand of funders, service providers, professionals and population ${ }^{21}$, highlighting the role of the media in reporting inadequacies in the quality and safety of patientcentered health services ${ }^{6}$. In this context, hospitals and other health institutions seek to evidence their positive results to the internal and external public through accreditation programs.

Hospital accreditation shows itself as a possibility to promote changes in the institution, in the habits, values and behaviors of the individuals involved, imposing the rupture of the mechanized care and reflecting in improvements in the quality of the services and health care ${ }^{4}$.

In the context under study, accreditation caused organizational and behavioral changes that initially generated insecurity and resistance in the collaborators. However, the development of strategies to improve internal communication contributed to the uniformity of information and greater understanding on the part of professionals about their actions, which caused changes in workers' attitudes, engagement and involvement with the process over time.

In the initial phase of the accreditation process, the information was concentrated in the management group and in the coordinators, but with the maturation of the process was horizontal, evidencing the improvement of the communication to maintain the certification. A study carried out in a hospital in Brazil showed that the concentration of information in the management group generated insecurity and lack of motivation of the professionals for adherence to the new work methodology, as well as barriers in learning and retention of knowledge ${ }^{4}$.

Thus, we agree with the authors ${ }^{4}$ that information and training on quality should be permanent and continuous for the maintenance of certification and greater adherence of professionals to changes and improvements in services. This observation points to the need for effective internal communication, in view of the fact that workers must be well informed so that they can become involved and act in accordance with the principles of quality and accreditation requirements.

Improvements in intra and intersectoral information exchange were also identified, allowing quality management to be seen as the result of an integrated work between the support, administrative and administrative areas, articulating the different knowledge in the search for better care and financial results. Accreditation promotes organization of workflow, optimization of the offer of diagnostic support services aligned to the demands of users. In addition, it promotes practices of management of financial resources, instigating the creativity and commitment of the multiprofessional team for the execution of actions that minimize $\operatorname{cost}^{22}$.

It should also be noted that the achievement and maintenance of certification signals the competence of the leadership exercised by managers, leaders and the entire hospital staff 22. Effective internal communication therefore promotes the development and maintenance of relationships between organizations, supervisors and employees for sharing ideas, experiences and knowledge, contributing to greater employee involvement with the work environment, and facilitating the ability of the professional to engage their values and objectives to those of the organization ${ }^{23}$.

In line with the results, the role of the manager is essential in the process of organizational change, highlighting among its functions: to contribute to the involvement of its employees, to explain the change plan, to encourage participation, to recognize the work of the team , to enable a clear, transparent and objective dialogue ${ }^{24}$

With regard to constant meetings between coordinators and teams, between quality assessment and the sectors, and between sectors and management, they contributed to the joint construction of the meaning of the accreditation process and to 
the alignment of its practices. For the success of quality management, therefore, employees must be convinced of the need and validity of their actions, and the manager is the link for building a joint thinking among the various social actors in quality policy.

Weekly meetings between teams, feedback of information with feedback, and the involvement of health professionals in the analysis of indicators are fundamental tools for achieving goals and greater engagement and autonomy of the team ${ }^{24}$. In addition, individual guidelines and multiprofessional meetings for the analysis and study of adverse events are key to joint accountability for patient safety ${ }^{25}$.

Deployment of strategic information to the operational level is essential for an accredited hospital that seeks to maintain certification, since the information passed on intermittently to all hierarchical levels enables the continuity of the changes and greater integration between the receivers, reaffirming the new culture of quality.

This change in behavior occurs not only through formal and written communication vehicles, but also through informal faceto-face communication, constituted by daily interactions between workers and leaders. Direct contact is one of the most relevant points to be absorbed for the effectiveness of communication, given that the importance of communication lies in interpersonal relationships and in the universe that allows the creation of relationships ${ }^{26}$.

In a study ${ }^{26}$ on situations in which dialogue was indispensable face-to-face among all operational levels, situations that required direct argumentation, such as discussion of ideas and negotiation, situations of conflict and decision in the short term. And in the case of changes of norms or internal rules, the dialogue was considered the most correct strategy, even if there were other alternatives of disclosure. This result is relevant in the context of accreditation, considering that the interaction role of the leader and the work team can help spontaneously and constantly in the dissemination of new rules, values and organizational norms.

Deployment information is to show new guidelines, teach how to follow them, and explain the reason for them, in order to promote behaviors consistent with organizational objectives. In this context, the hospital under study used written and oral communication vehicles, in which the written communication was directed to information disclosure and dissemination to all employees, and oral communication for the disclosure and validation of the understanding of this information, receiving feedback from recipients with the objective of promoting behavioral changes, aiming at better institutional results. Communication implies exchanges and understandings, which are only possible when considering, in addition to words, the emotions and the situation in which the sharing of knowledge, ideas, instructions and other messages occurs ${ }^{26}$.

Thus, managers and coordinators must identify the information needs and the degree of knowledge of their teams, aiming at adapting the language to be used in the multiple channels of communication. It should be emphasized that one of the great challenges of accreditation is the understanding of the quality requirements and the strategies to reach them by all those involved in the process, and an effective, accessible and adapted communication is necessary for the understanding of the different audiences ${ }^{27}$.

The findings indicate that strategies for improving communication were essential for the consolidation of hospital accreditation. Changes were evidenced in the perception of professionals in relation to the certification process, which came to understand the proposal of quality certification, which is beyond meeting the criteria for audits, but mainly to incorporate the requirements in the daily practice for safety the patient and the professional.

\section{Study limitations}

It should be stressed that the considerations must be tested in new studies, which may present different nuances, depending on the new scenarios and subject to be studied, considering that this research is presented as a single case, with individual interviews addressing a hospital context singular. The use of qualitative research results is done by readers or final consumers when they perceive similarities of contexts and situations.

\section{CONCLUSIONS}

Strategies for effective communication were essential for the internalization of quality principles in professional practice at the hospital under study, resulting in improved services and consolidation of certification. Among the communication strategies identified, the deployment of strategic information up to the operational level and improvement in the use of written and oral communication tools. These strategies allowed for changes in the employees' perception about accreditation, such as greater awareness and involvement in the process, thus promoting behavioral changes.

Therefore, the effectiveness of the communication with the deployment of the strategic planning is indispensable for an accredited hospital with excellence that aims at the maintenance of the certification, since the information passed on continuously to all operational levels enables the continuity of actions and encouraging the change of attitude of individuals, reaffirming the culture of quality. The workers are in charge of putting the planned actions into practice and must be engaged in the certification process. Thus, the communication assumes a prominent role and should be a priority strategy to reach and maintain accreditation, aiming at the quality of care and patient safety.

With regard to contributions to the Nursing and Health field, we expect that this study will boost discussions and awaken the awareness of nurses and managers about the importance of communication for the strengthening of health quality management systems and should be used as much as tool for health care security, as well as a strategy for consolidating accreditation programs. We hope that this work may subsidize the construction of hospital communication strategies aimed at the maintenance of accreditation, in order to strengthen the execution of the processes according to quality requirements in the daily hospital work. 


\section{FINANCIAL SUPPORT}

Funding Support from 'Fundação de Amparo à Pesquisa do Estado de Minas Gerais - FAPEMIG' to the Research Project "Quality management and patient safety in emergency health services" (Registered Nr. APQ-00353-15).

\section{REFERENCES}

1. Reis CT, Martins M, La Guardia J. A segurança do paciente como dimensão da qualidade do cuidado de saúde: um olhar sobre a literatura. Ciênc Saúde Coletiva [Internet]. 2013; [cited 2018 Jan 12]; 18(7):2029-36. Available from: http://www.scielo.br/pdf/csc/ v18n7/18.pdf

2. Lucena AF. Processo de enfermagem: interfaces com o processo de acreditação hospitalar. Rev Gaúcha Enferm [Internet]. 2013; [cited 2018 Jan 12]; 34(4):8-9. Available from: http://www.lume.ufrgs.br/bitstream/ handle/10183/96804/000914930.pdf?sequence $=1$

3. Organização Nacional de Acreditação - ONA.Manual de acreditação das organizações prestadoras de serviços de saúde. São Paulo: Organização Nacional de Acreditação [Internet]; 2018 [cited 2018 Jan 12]. 152 p. Available from: https://www.ona.org.br/Produto/282/ Manual-Brasileiro-de-Acreditacao-Organizacoes-Prestadoras-deServicos-de-Saude-Versao-2018

4. Manzo BF, Brito MJM, Alves M. Influência da comunicação no processo de acreditação hospitalar. Rev Bras Enferm [Internet]. 2013; [cited 2018 Jan 12]; 66(1):46-51. Available from: http://www.scielo.br/pdf/reben/ v66n1/v66n1a07.pdf

5. Ochoa CG. As diferenças entre comunicação interna e endomarketing. ECCOM [Internet]. 2014; [cited 2018 Jan 12]; 5(9):107-18. Available from: http://fatea.br/seer/index.php/ eccom/article/viewFile/819/581

6. The value and impact of health care accreditation: a literature review. Ottawa: Accreditation Canada [Internet]; 2015 [cited 2018 Mar 5]. 17 p. Available from: https://aventa.org/pdfs/valueimpactaccreditation.pdf

7. World Health Organization. The high 5 s project: interim report. Geneva: World Health Organization [Internet];2014 [cited 2018 Mar 5]. Available from: https://www.who.int/patientsafety/implementation/solutions/ high5s/High5_InterimReport.pdf

8. Lingard L, Espin S, Whyte S, Regehr G, Baker GR, Reznick R, et al. Communication failures in the operating room: an observational classification of recurrent types and effects. Qual Saf Health Care [Internet]. 2004; [cited 2018 Mar 5]; 13(5):330-4. Available from: https:// www.ncbi.nlm.nih.gov/pubmed/15465935

09. Hamester MMM, Moura GL, Fishmann AA, Gaspary E, Balsan LAG. O papel comunicativo dos colaboradores para a política nacional de humanização: o caso de um hospital universitário. RAHIS Rev Adm Hosp Inovação Saúde [Internet]. 2015; [cited 2018 Mar 5];12(2):3443. Available from: http://revistas.face.ufmg.br/index.php/rahis/article/ view/2377/1578

10. Welch M. Appropriateness and acceptability: employee perspectives of internal Communication. Public Relat Rev [Internet]. 2012 Jun; [cited 2018 Mar 5]; 38(2):246-54. Available from: https://www.sciencedirect. com/science/article/abs/pii/S0363811111002128

11. Organização Nacional de Acreditação. ONA. Certificações válidas [Internet]; 2019 Jan [cited 2019 Jan 10]. Available from: https://www. ona.org.br/OrganizacoesCertificadas

12. IQJ. Heath Service Accreditation [Internet]; 2018 [cited 2018 Mar 7]. Available from: http://www2.iqg.com.br/instituicoes/o-que-a-iqg-fazpela-sua-instituicao-de-saude/\#
13. Consórcio Brasileiro de Acreditação. Unidades Acreditadas no Brasil [Internet]; 2018 [cited 2018 Mar 7]. Available from: http://www.cbacred. org.br/unidades-acreditadas-no-brasil.asp

14. Whittington R.Strategy after modernism: recovering practice. Eur Manage Rev [Internet] 2004; [cited 2018 Mar 7]; 1(1):62-8. Available from: https:// onlinelibrary.wiley.com/doi/abs/10.1057/palgrave.emr.1500006

15. Golsorkhi D, Rouleau L, SeidI D, Vaara R. Introduction: what is strategy as practice? In: Golsorkhi D, Rouleau L, Seidl D, Vaara R, eds. Cambridge Handbook of Strategy as Practice. New York: Cambridge University Press; 2010.

16. Canhada DID, Rese N. Implementação de estratégias: barreiras e facilitadores evidenciados na literatura brasileira especializada Future Stud Res J [Internet]. 2011 Jan-Jun; [cited 2018 Mar 5]; 3(1):38-58. Available from: https://www.revistafuture.org/FSRJ/article/ viewFile/30/117

17. Yin RK. Estudo de caso: planejamento e métodos. Porto Alegre: Bookman Editora; 2015.

18. Minayo MCS. O Desafio do Conhecimento: Pesquisa Qualitativa em Saúde. São Paulo: Hucitec; 2010.

19. Fontanella BJB, Ricas J, Turato ER. Amostragem por saturação em pesquisas qualitativas em saúde: contribuições teóricas. Cad Saúde Pública [Internet]. 2008 Jan; [cited 2018 Mar 5]; 24(1):17-27. Available from: http://www.scielo.br/pdf/csp/v24n1/02.pdf

20. Bardin L. Análise de conteúdo. 4ํㅡ ed. Lisboa: Edições 70; 2009.

21. Machado JP, Martins ACM, Martins MS. Avaliação da qualidade do cuidado hospitalar no Brasil:uma revisão sistemática. Cad Saúde Pública [Internet]. 2013 Jun; [cited 2018 Mar 5]; 29(6):1063-82. Available from: http://www.scielo.br/pdf/csp/v29n6/a04v29n6.pdf

22. Camillo NRS, Oliveira JLC, Belluci Júnior JA, Cervilheri AH, Haddad MCFL, Matsuda LM. Acreditação em hospital público: percepções da equipe multiprofissional. Rev Bras Enferm [Internet]. 2016 Mai-Jun; [cited 2018 Sep 16]; 69(3):451-9. Available from: http://www.scielo.br/ pdf/reben/v69n3/0034-7167-reben-69-03-0451.pdf. DOI: http://dx.doi. org/10.1590/0034-7167.2016690306

23. Karanges $E$, Johnston $K$, Beatson A, Lings I. The influence of internal communication on employee engagement: a pilot study. Public Relat Rev [Internet]. 2015 Mar; [cited 2018 Mar 5]; 41(1):129-31. Available from: https://www.sciencedirect.com/science/article/abs/pii/ S0363811114001969

24. Siman AG, Cunha SGS, Martins ES, Brito MJM. Estratégia do trabalho gerencial para alcance da acreditação hospitalar. Rev Min Enferm [Internet]. 2015; [cited 2018 Mar 5]; 19(4):815-22. Available from: http://www.reme.org.br/artigo/detalhes/1043. DOI: http://www.dx.doi. org/10.5935/1415-2762.20150063

25. Siman AG, Brito MJM. Mudanças na prática de enfermagem para melhorar a segurança do paciente. Rev Gaúcha Enferm [Internet] 2016; [cited 2018 Sep 16]; 37(spe):e68271. Available from: http://www. scielo.br/scielo.php?pid=S1983-14472016000500413\&script=sci abstract\&tlng=pt. DOI: http://dx.doi.org/10.1590/1983-1447.2016. esp.68271

26. Martins MTMC. Diálogo e interações face a face: a força da oralidade na comunicação interna. Organicom [Internet]. 2013; [cited 2018 Mar 5]; 10(19):184-98. Available from: http://www.revistas.usp.br/organicom/ article/view/139203

27. Hinchcliff R, Greenfield D, Westbrook JI, Pawsey M, Mumford $\mathrm{V}$, Braithwaite J. Stakeholder perspectives on implementing accreditation programs: a qualitative study of enabling factors. BMC Health Serv Res [Internet]. 2013; [cited 2018 Mar 5]; 13:437. Available from: https://bmchealthservres.biomedcentral.com/ articles/10.1186/1472-6963-13-437

a This study was funded by the Coordenação de Aperfeiçoamento de Pessoal de Nível Superior (CAPES - Coordination for the Improvement of Higher Education Personnel), a doctoral scholarship to the author Elana Maria Ramos Freire. 


\section{ERRATUM}

In the article "Communication as a strategy for hospital accreditation maintenance", with DOI number: https://doi. org/10.1590/2177-9465-ean-2018-0224, published at the Journal Escola Anna Nery, 2019; 23(1): e20180224, page 8, was included the section Financial Support wih the following text: "Funding Support from 'Fundação de Amparo à Pesquisa do Estado de Minas Gerais - FAPEMIG' to the Research Project "Quality management and patient safety in emergency health services" (Registered Nr. APQ-00353-15)". 